\title{
Report of the Committee on Secondary School Geography: Read before the National Education Association Convention, July 3 to 9, 1909
}

\section{Chairman James F. Chamberlain}

To cite this article: Chairman James F. Chamberlain (1909) Report of the Committee on Secondary School Geography: Read before the National Education Association Convention, July 3 to 9, 1909, Journal of Geography, 8:1, 2-9, DOI: 10.1080/00221340908986218

To link to this article: http://dx.doi.org/10.1080/00221340908986218

曲 Published online: 20 May 2008.

Submit your article to this journal $\pi$

山 Article views: 3

View related articles 


\section{THE JOURNAL OF GEOGRAPHY}

VoL. VIII.

SEPTEMBER, IgO9

No. I

\section{REPORT OF THE COMMITTEE ON SECOND- ARY SCHOOL GEOGRAPHY}

Read before the National Education Association Convention, July 3 to 9, 1909

By James F. Chamberiatn, Chairman

State Normal School, Los Angeles, Cal.

TCHE expression "the new geography" is now so infrequently heard that it may be of value to remind ourselves of its former significance. The appointment by the National Education Association in 1892 of the Committee of Ten was an important event in the development of school subjects in general, and of geography in particular.

The report of the Conference on Secondary School Geography crystallized and gave definite and authoritative expression to the belief, which for a number of years previous to this had been a conviction on the part of the few leaders in the subject, that earth science should be a broader, deeper, more helpful study than it then was. It regarded the subject not as a mere description of the most striking features of man's physical environment, but as a study of the evolution of environment, and its relations to human conditions. It recognized the fact that if geography was to maintain a place in the secondary school as a subject for serious study, it must experience a decided change in character. As the laboratory method was being used with success in chemistry, physics, and the biological sciences, it was considered wise to apply it to geography.

The close relations between geology and geography, the fact that the former was quite well organized and that there was material available for laboratory work, together with the personnel of the Conference, all combined to give the movement a decided trend in the direction of geology or physiography. Because there were no text-books that treated the subject from the new point of view, the Conference recommended that physical geography, along the lines then followed, be presented in the first year of the high school, and physiography or geology in the last year. 
taken in the near future, will be of greater importance than that inaugurated sixteen years ago.

Although the economic and commercial phases of geography are receiving an increasing amount of attention, secondary school geography is to-day practically physiography. Therefore, unless otherwise specified, all references here made to geography as now taught in the high schools have to do with this division of the subject. The following are the more important reasons for considering a change in the nature of the course imperative:

I. The course, as at present organized, places too much emphasis upon the detailed study and classification of land forms, and too little upon human response to those forms. The amount of space devoted to the lands by the various physical geographies varies from forty per cent. to seventy-six per cent. of the total. The criticism here made, however, is not that too much space is devoted to the lands, as one of the four great divisions of physical geography, but that the lands are not sufficiently studied from the geographic point of view, namely, the human.

2. A concrete study of human response to its environment does not receive sufficient attention. This point has reference to all of the divisions of the subject. Your committee recognizes the fact that a comprehensive study of this subject, as applied to large areas, is impossible in a brief course devoted to physical geography. The omission of such study from secondary school geography is a serious matter, however. A careful examination of our texts will show that the facts and principles stated are given scant application to concrete areas. The newer books show an improvement over the old ones in this respect.

3. The course aims to fit the student for college rather than for the affairs of life. Secondary school geography, as a part of our educational scheme, should agree with the latter in so far as general function is concerned. In other words, it should aim to render the greatest possible service in preparing the student to meet successfully the opportunities and obligations of life. The fulfilling of college entrance requirements-a matter which now receives serious attention--should receive practically no consideration. The soundness of this statement becomes evident when it is remembered that only about ten per cent. of the total enrollment in public and private high schools graduate. In other words, practically all graduates of secondary schools enter at once upon some business, some profession, or the duties of home life. It is to these students, more than ninety per cent. of the total number, that the secondary school should 
devote itself heart and soul. The popular, but false conceptiun, that the high school should place great emphasis upon meeting college entrance requirements in geography as well as in other subjects, is responsible for certain conditions in the curricula of our secondary schools that are much to be regretted.

4. Secondary school geography does not give the student a grasp of the natural resources, the industries and the commerce of the world. This condition is, of course, inevitable so long as the geography in the secondary school is almost exclusively physical geography. The training which this phase of the subject, when properly presented, affords is too valuable to be neglected. Especially is this true as applied to our own country.

5. Geography in the secondary school does very little as a preparation for the teaching of that phase of the subject which, in the elementary school, receives chief attention. Your committee recognizes the fact that it is not the special function of the high school to prepare its students for any particular occupation or profession. But as the training of children is the most important work in which any one can engage, most important both from the standpoint of the home and the nation; and as a considerable number of teachers is yearly drawn from the ranks of high school graduates, we conceive it to be a part of the function of the high school, until such time as professional training for the work of teaching is universally required, to give its graduates such work as will best fit them for teaching; provided that it is at the same time of great value to the many who will not teach.

We do not imply that a good course in physical geography does nothing toward preparing the graduate of the secondary school to teach in the grades, but it omits those phases of the work essential in the elementary school, and which are at the same time of most importance to the average member of society.

6. Secondary school geography, as at present constituted, can not give the student that knowledge of the regions and peoples of the world which intelligent participation in the affairs of life requires. If broadly interpreted, this encompasses all of its weaknesses. By its very nature high school geography places a handicap upon the student who tries to do advanced work in the subject. The lack of a knowledge of place relations, and of regional geography in a broad sense, is a weakness so universally shown by students in the entering classes of both normal schools and colleges as almost to discourage teachers of geography in 
those institutions. It is this knowledge which the average person, no matter in what walk of life, most needs. The farmer, the fruit grower, the stockman, the miner, the promoter of railroads or waterways, the manufacturer, the shipper, the fisherman, the artisan, the health seeker and the traveler all feel its need daily. We can not read with intelligence the daily papers and the periodicals, not to mention history and literature, without some considerable knowledge of regional geography.

We present the following as essentials of a course in geography for secondary schools:

I. Those parts of mathematical geography which show most clearly how human life is influenced by the relations between the earth and other members of the solar system. Such points as the arrangement of the mathematical and heat zones and the varying boundaries of the latter; the change of seasons; latitude and longitude; standard time and the International Date Line are important. Facts as to the size of the members of the solar system, their distances from the earth or sun, and their periods of rotation and revolution are not considered essentials.

2. First in importance among the factors influencing life is climate. Therefore, atmospheric phenomena should receive careful attention. The principles should be applied as fully as time and the ability of the students permit. The topics which should receive chief attention are the following: (a) The conditions determining the temperature, pressure and humidity of the atmosphere. (b) The great atmospheric movements. (c) Storms, especially temperate latitude cyclones, studied by means of the weather maps, and their relations to crops, floods and transportation. (d) Precipitation; its causes and distribution; and its influence upon occupations and habits of life generally. (e) Weather changes, such as the effect of unseasonable frosts upon crops, and the efforts of man to prevent the damage. The influence of blizzards upon stock on the western ranges, and telegraph and railroad business in many parts of the country. The effects of storms upon wheat, oats, hay and other crops. (f) We urge the importance of a study of the work of the Weather Bureau, having students present specific illustrations of the value of its work. Comparatively few realize the multitude of human interests that are advanced through the operations of this bureau.

3. A brief study of the ocean as a modifier of climate, as an agent in the destruction and construction of land forms, as the source of certain commodities, and as a medium for the transmission of the commerce of the world. 
A detailed study of ocean depths, of temperatures at various levels, of tides, of the character and distribution of ocean life may well be omitted.

While our texts treat the ocean as a separate division of physical geography, we favor an incidental treatment, with a brief summary. The influence of the ocean upon climate-the topic of chief importanceshould be considered in connection with the study of climate. Erosion and sedimentation along shore lines should be treated under those topics. The commodities obtained from the ocean, as well as the commerce which it bears, would naturally receive attention as a part of commercial geography.

4. The larger geographic forms such as plains, plateaus, mountains, valleys, rivers, falls, lakes and glaciers should receive careful study. Human interests and activities are largely confined to the lands, but it is obviously of far greater importance that we should understand our relations to geographic forms than that we should have a thorough knowledge of their evolution, or be able accurately to classify them.

Graduates of secondary schools should know the location of the great plains of the world, and how they are related to the production of food, of occupations, of transportation and the distribution of population. Whether or not these students can name the six or eight classes of plains given in our text-books is a matter of very little importance. Students should understand how certain definite mountains influence climate, the distribution of plant life, human occupation of their areas, the construction of railroads, the use of streams for transportation and the development of water and electric power, how they served as national boundaries and have helped to mold national characteristics. The ability to name the different types of mountains, and to classify faults and folds is of little value to the average person, however. In other words, it is the human point of view that is important as applied to every topic.

Students should be encouraged to discover human response to its environment in the home area, as this gives reality to the subject and prepares them to work out and appreciate these relations in remote areas.

The amount of emphasis placed upon the study of the various geographic forms and processes will depend, in part, upon the location of the individual school. A school situated in a mountainous region would very properly devote more time to the consideration of the influence of mountains upon life than would one in the prairie section. In the firstnamed area the relation which mountains bear to climate, industries, 
settlement, and road building are relatively of greater importance than in the second, because they are at hand and are therefore more meaningful.

5. A study of the larger features of the resources of our country, such as its soils, waterways, water powers, forests and mineral wealth. These features of our geographic environment are so vitally connected with the daily life of every individual, as well as with our national progress, that ignorance of them is a serious matter.

This study should show the distribution of the resources, their accessibility, their relation to road building, to distribution of population, to development of industries, to location and growth of cities, to commerce, and to social conditions. The work of our government in modifying geographic environment should receive careful consideration. Our government is expending vast sums of money in carrying on soil surveys, in improving plants and animals, in reclaiming desert and swamp lands, in the preservation and extension of forests, in developing waterways and harbors. These are subjects upon which every man and woman should be informed from the geographic point of view. The value of such work in the molding of useful members of society is certainly very great.

6. A knowledge of the general geography of the most important countries and peoples of the world.

The grasp of regional geography obtained in the elementary school is necessarily very meager. Geography is quite generally discontinued in the seventh grade, and, as has been stated, practically no attention is given to regional geography in the high school. A knowledge of the geography of our own country and of Europe is a much-to-be-desired factor in good citizenship. A somewhat detailed study of these two regions would incidentally put the student in possession of considerable knowledge of the other continents. In addition to this he would gain a "geographic consciousness" that would be of great value.

If it be true that a large part of the education of the average individual comes through reading, then it is of the utmost importance that we should be able to read intelligently. This, in the fullest sense, is impossible unless one's knowledge of geography is wider than that offered by the present high school course in this subject.

7. Some conception of how the history of nations has been shaped by geographic conditions.

We do not forget that this should be a vital part of all courses in history, but it should also receive very definite attention in secondary 
school geography. All nations afford illustrations of this, some more than others. That our own country is a fruitful field is evidenced by such works as Brigham's Geographic Influences in American History, and Miss Semple's American History and Its Geographic Conditions.

8. The ability to trace, in the large, the relationships between the most important geographic forms and geographic processes, and to appreciate the responses which human life everywhere makes to its physical surroundings.

Only as the student has observed the results of geographic processes on a small scale can he have any definite conception of the evolution of larger and distant geographic forms. When the student appreciates the significance of human response in the vicinity of his home, he has laid the foundations for the discovery and interpretation of this response in remote areas. Moreover, this training will furnish some basis for seeing in advance the general trend of the geographic development of a new region.

In order to make it possible to present the essentials as herein outlined, your committee makes the following recommendations:

1. Geography, touching as it does the daily life of every individual at so many points, should be, in some form, a required subject in all secondary schools.

Sixteen years ago the Committee of Ten recommended that physical geography be required in all high school courses. While we recognize the importance of physical geography, we feel that this is too restricted a view, and that, as already pointed out, it does not include those phases of geography which are of greatest value to the average individual.

2. The subject should be pursued for not less than one year.

While more than one year is very desirable, we feel that through careful selection of topics and the elimination of unimportant details, very much can be accomplished in the time stated.

3. The subject should be presented during the first year of the high school course.

Such an arrangement will connect the work with that of the elementary school with the least possible break in time. It will also help the student in such work as he may take in history, literature, economics, geology and meteorology. A third advantage is that it will reach a larger number of students than it will if presented later in the course.

4. There should be at least five recitation periods per week.

5. About one-fourth of the total time should be devoted to laboratory and field work. This should by no means be confined to the study of 
physical geography. Much laboratory work and some excursions should be undertaken in connection with the commercial phase of the subject, and there should be carefully planned exercises based upon maps and models.

We recommend that about one half-year be devoted to the larger topics in physical geography, with the human side made more prominent than at present, and that the remainder of the year be given to a study of North America and Europe.

Such a course would give our students some considerable knowledge of the geography of the most important countries of the world, and incidentally much useful information, as applied to other areas, would he acquired.

The chief difficulties that stand in the way of putting such a course into operation are two: first, time-honored custom, and second, the lack of text-books that meet the requirements. We believe that careful consideration of the subject from all points of view will remove the first, while the publishers will provide us with the necessary texts almost as soon as we declare ourselves ready for them. In the meantime, the first part of the course can be carried on by means of selected portions of our physical and commercial geographies, numerous government publications, and periodical literature.

The work of your committee has been carried on under great difficulties. Its members live in widely separated parts of our country and hence there has been no opportunity for conference. While we are not unanimously agreed upon every point herein mentioned, we find ourselves in hearty agreement on the report as a whole. If the conclusions here reached are pointed in the right direction, and shall help to bring out a more fruitful. study of one of the most practical as well as one of the most broadening and humanizing of subjects, we shall have been well repaid.

James F. Chamberlain, Los Angeles, Cal., Chairman.

M. L. W. Field, Milton, Mass.

Mrs. Martha Krug Genthe, Hartford, Conn.

Mark Jefferson, Ypsilanti, Mich.

WM. C. Moore, South Hadley, Mass.

W. H. SNYdER; Hollywood, Cal.

R. H. Whitbeck, Madison, Wis. 